\title{
Forum
}

\section{斜面防災対策技術をめぐる諸問題 一地すべり技術の伝承問題によせて一}

\section{鴨井幸彦（侏村尾技建）}

\section{【問題点のありか】}

当学会では，2013年 5 月24日に行われた総会シンポジ ウムのパネルディスカッションで「地すべり技術・経験 の継承」が取り上げられた。地すべり学会に限らず，近 年はいろいろな分野で「技術の伝承」の重要性が指摘さ れ，さまざまな取り組みがなされている。

たとえば, 全国地質調査業協会連合会では, 早くから この問題に注目し, 技術情報誌である「地質と調查」の 2007年第 3 号（通巻113号）で特集を組んでいる”。また， 地盤工学会でも，学会誌の 2009 年 1 月号で特集したほ か，2011年10月号から 6 回にわたって講座で連載してい $b^{2}$ 。

周知のように，斯界における技術伝承問題の背景とし て, (1)斜面防災関連業界を背負ってきた, 現場経験豊富 な団塊世代やそれに続くポスト団塊世代の相次ぐ引退,

(2)若年技術者の減少, (3IT技術の進歩による作業内容 の変容 (内業が増え, 現場へ出向く機会が減少した),

(4)公共事業費削減に伴う業務量の減少（現場数，つまり 修練の場の減少）など，さまざまな要因を挙げることが できる。いずれも難問で，これといった決め手となる解 決策をもたないというのが現状であろう。どの学会も若 年層の会員減少に頭を抱えている。

このうち，(1)，(2)は日本全体に共通した課題であり， 産業構造の変化や生産年齢人口の減少 (人口減社会への 突入）に起因した構造的な問題である。一方，斜面防災 分野では, 社会環境の変化による要因 (3)と(4) がこれ に加わる。とりわけ，1,000兆円を越える膨大な量に上 る国の借金(国債及び借入金並びに政府保証債務現在高) や，公共事業全体に占めるメンテナンス費用の急増問題 等を背景に“節約時代”に入った公共事業のありようは, 自ずと変わらざるを得ないことは明らかである。

以上のような経緯を踏まえ，ここでは現状の地すべり 対策のかかえる問題点をいくつか指摘し, 私見を述べ, 各位の議論の参考に供したい。なお，以下に述べる内容 の一部は, 2012年 5 月18日に実施された当学会新潟支部 創立40周年記念シンポジウムで報告したものである゙”。

\section{【伝承の問題】}

技術の伝承問題に関連して「温故知新」という成語を 見聞きすることが多い。日本人なら誰でも知っているこ
の有名な論語（為政第二の十一）に由来する四字熟語は, 一般的には「古いことをよく勉強した上で，さらに新し い知見を加える」という意味で使われる。つまり，こと さら新しいことにばかりに目を向けるのではなく, 古く から伝わる良いこともしっかりと繰り返し学んで十分に そしゃくした上で, 新しい視点や知識を取り入れなけれ ばならない，という主張と帱察する。

しかし，実はこの部分だけを切り取ったのでは不十分 で，それに続く「以て師たるべし」と一緒になって初め て孔子の真意が伝わるもののようである。すなわち，技 術の伝承を担う人（教える側の人）には，技術に関する 歴史的な経緯や基礎的な知識をしっかりと身につけた人 こそがふさわしいということである。

本稿で，あえて私がこの点に触れたのは，伝える側に も問題があるとしばしば感じるからである。悪いところ （それは技術であったり慣習であったりする）は，反面 教師としてのみ伝承し，技術として引き継いではならず， 逆に古いことであっても確実に伝えなければならない内 容がある。

\section{【高野秀夫さんに学ぶ】}

筆者は地方の地質調查会社に勤務し, 30年以上にわ たって地すべり等の斜面災害の調査にたずさわってきた 地質技術者であるが，たまたま最初に入社した会社で， 日本の地すべり研究の草分けともいうべき高野秀夫さん が非常勤の顧問をされていた。そこで，折に触れて，地 すべりにまつわるいろいろな問題について直接話をうか がった。1981年当時である。

高野さんは，そのしばらく前, 1976年から不定期に地 すべり学会誌に<随想 >を寄稿され, 銀座地すべりやや 空論の法則 ${ }^{5}$ といった意表を突く巧みなタイトルで, 地 すべり研究の現状や調査・対策のあり方等について, 舌 鋒鋭い議論を展開されていた。投稿は1984年まで18回に わたり，一部からは煙たがられていたようである。高野 さんの主張の一部は, 現在でも十分に通用する内容であ る。温故知新というからには, まずこの辺から入る必要 があるように思われる。

私が打会いしたのはちょうどその頃で，それらの思い を直にうかがったわけである。高野さんはのちに，長年 の現地調查や研究で得られた知見や見解を「斜面と防災」 
という著書にまとめられだ)。現在，同書は品切れで再 版の予定もないようであるが，大きな図書館では閲覧可 能と思われる。なお，地すべり学会誌の＜随想 $>$ は，JSTAGEで読むことができる。若い人のみならず，中堅 技術者にも是非一読して欲しいと願うものである。

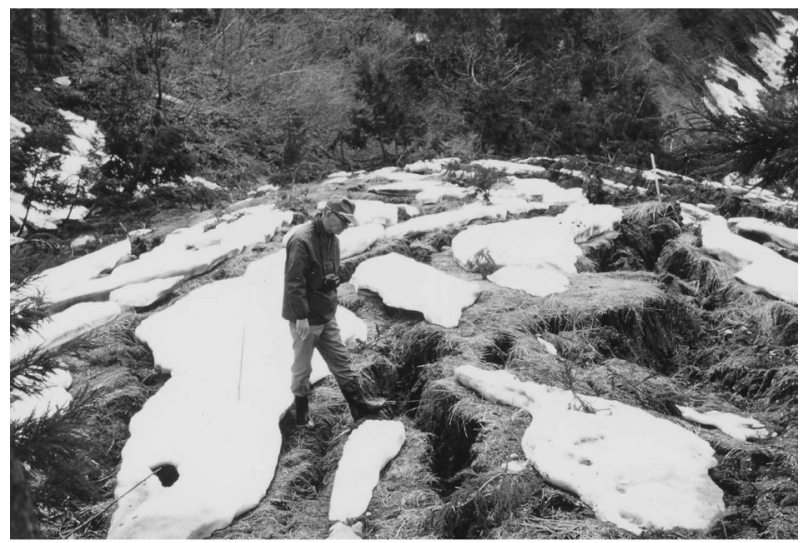

写真一 1 新潟県の中束（なかまるけ）地すべりの隆起部を 観察する高野さん（1981年 4 月18日）。高野さん と初めて出向いた現場である。

\section{【節約時代におけるの公共事業のあり方】}

日本列島は変動帯にあるため地殸変動（隆起や沈降運 動）が活発で, 大陸に比べ地形の変化が大きく, 亀裂や 断層が密に発達している（かつて，構造地質学の大家で ある大阪市立大学名誉教授の藤田和夫先生は，その様子 を日本砂山列島”あるいは傷だらけの日本列島 ${ }^{8}$ と表現さ れた)。そのため, 地質は総じてもろく, 土砂の生産量 が多い。しかも，アジアのモンスーン地带に位置してい るため降水量が多く, 河川の侵食・運搬力は旺盛である。 このため，土砂災害や豪雨災害が頻発し，さらに火山の 噴火や地震も多く発生するなど，古来多くの自然災害に 見舞われてきた。こうした日本列島のおかれた自然環境 を理解しているため，これまで，国民の多くは防災・減 災事業や災害復旧に対して比較的寛容であった。

しかし，いまや社会環境が変容し，公共事業に対して は，「あれもこれも」と要望を先取りしてでも実施する 時代から，対象を厳選して大幅に絞り込む「あれとこれ (のみ)」といった時代へと移行しつつある。いわば予算 の節約（圧縮）時代の到来である。これからは，防苂・ 減災や災害復旧事業に対しても厳しい目が向けられるに 違いない。そうした公共事業の節約時代において，斜面 防災分野にはどのような取り組みが求められるだろうか。 ここでは主に三点を指摘したい。

まず一点目は，当たり前のことであるが，適切かつ正 確な地質調查に基づき，現場状況に適合した，経済的で 誰の目にも納得できる工種と数量を提案することである。 というのは，どうしてこの工種をここで選択したのか， どうにも合点がいかない現場をしばしば目にするからで ある。さらに，地質断面図が現地状況と合致せず，すべ
り面形状や地すべり機構に疑いがもたれるケースも少な くない。これまでは, ともすると限られた関係者だけが 情報を持ち, 議論も避けがちな傾向が見られたが，これ からは第三者の目が入っても胸を張れるだけの内容を提 示していく必要があろう。

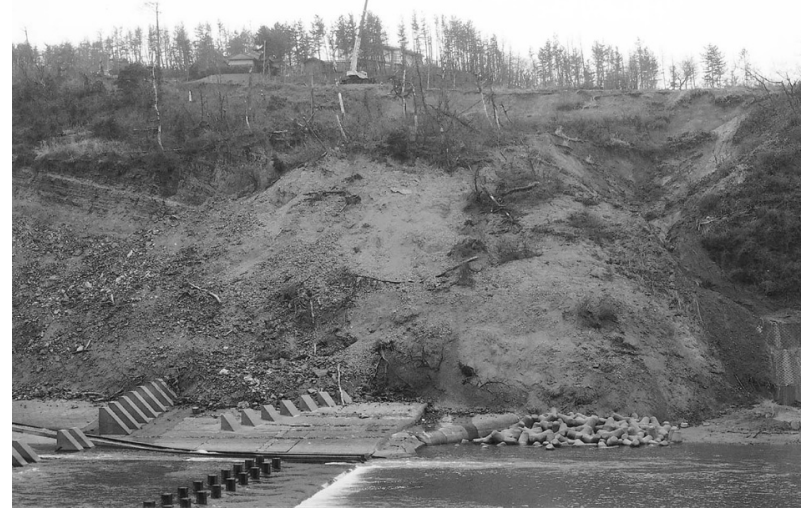

写真一 2 大正時代に開削されたある放水路において, 左岸 側切り土のり面で発生した崩壊。くさび型崩壊で あることは写真でも明らかであるが，なぜか円弧 すべりとして解析された。基岩層は中部中新統の 砂岩泥岩互層（フリッシュ相）で，15 20で西 側（下流側）へ傾斜した同斜構造を呈する。

二点目は, 「公共事業の節約時代」をうけ, 防災・減 災事業の内容や対象の思い切った絞り込みが不可避とい う点である。この場合，新規事業だけでなく，維持や更 新対象も例外ではない。まずは技術者の視点を第一に, 事業対象に対して客観的に優先順位を付ける。行政は, それを参考に, 重要度 (必要度) という観点から総合的 に判定し，予算を付け，執行していくという形が求めら れるであろう。

三点目は，大規模地すべりに対する計画安全率の考え 方の問題である”。大規模地すべりの場合，復旧や防止 対策にかかる工事費は非常に大きなものとなる。一方, 地震地すべりを除いた大規模地すべりの多くは, 動きが 緩慢なことが多く，このことは安全率のわずかな変化で 動き出したり沈静化したりする運動特性をもつことを示 唆している。地すべり一般について, 渡 $(1994)^{100}$ や奥 園 $(2009)^{11}$ は，経験上，いずれも安全率で10\%程度上 がれば，地すべりは打打むね静止するという見解を示し ているが，動きがゆっくりしているという大規模地すべ り一般の性状を踏まえ, 計画安全率 $\mathrm{FS}=1.10$ を基本に すれば，工事費は大幅に縮減可能である。しかし，現場 によっては，人家に近接しているとか，国道に面してい るとか, 将来的に不安定要因が加わる可能性が高いなど, $\mathrm{FS}=1.10$ でな扔不安を打ぼえるケースもあると考えら れる。そうした場合には, 理由を明示した上で, 現場状 況に応じて安全率を $\mathrm{FS}=1.10$ から FS = 1.20までの間に 適切に設定すればよい。 


\section{【斜面防災対策の将来】}

このところフィールドサイエンスの現状と将来に対す る悲観論を聞くことが多い（実のところ，どちらかとい えば筆者も悲観的な方に与している)。この問題は，地 質学 (とくに層位学や古生物学) や生物学（とくに分類 形態学や生態学) など, 野外を研究対象とした学問分野 に共通したもので，当該分野で急速に研究者の層が薄く なっている。たとえば, 古生物学分野では, 大型化石を 鑑定できる人が現役世代から消えつつある。もちろん， 現地調査に基礎をおく地すべり学もこの分野に含まれる であろう。

地すべり調査において, 現地で得られる情報は空中写 真や地図情報などに比べ格段に多い。実際, 現場へ来て 初めて気づき, 合点することも多い。何よりも, 現地を 前にして体感することが大切である。ふつう, 現地調査 の段階で, 調查計画や地すべり機構, 対策工のあらまし を想定してしまうものである ${ }^{12)}$ 。そして，この段階で， 技術者の個性や力量が表れる。現地調査の出来不出来は, 事業全体の成否を左右しかねないため, その役割は大き い。しかし，その意義は，残念ながら発注者サイドには 十分に理解されていない向きがある。それは，地表踏査 が積算体系の中で重きをなしていない点に端的に示され ている。

現在，多くの中小の地質調査会社では，地質技術者が 低賃金・長時間労働の中で疲弊している。そのような状 況では，若手技術者の参入はなかなか望めない。加えて， 現在の若者の多くは子供時代に野外で遊んだ経験がそし いためか，山野での身のこなしにぎごちない面が見受け られる。そのため, 外業よりも内業を好む傾向があり, ますます現場踏査力は落ちていく。現場の数も減り, 修 練の場が減って悪循環におちいる。しかし，現場の数が 減っても, 多くの現場を見学したり事例を学ぶことであ る程度補うことは可能と考える。この点で当学会の果た す役割は大きい。それだけに，現状の現地見学会（検討 会）のあり方について，もう一工夫する必要があろう。

こうした現状を変えることは至難の業であるが，その 解決策として，まず地質調査業に関わる技術者の労働環 境の改善が必要であろう。そのためには, 発注者によっ て地表踏査の意義が認識され, 評価される必要がある。
言うまでもなく，その前提として，信頼性の高い地表踏 査・現地調査が行われているという実態や実績が必要と なる。どの分野にも共通したことではあるが，その仕事 に対してやりがいと誇りが持て，しかも納得できる対価 が得られるようになってはじめて, 有為な人材の確保と 定着が可能となる。

最後に，防災・減災事業でもっとも重要な点を改めて 指摘したい。それは，「その地域の地形や地盤条件に合 わせた土地利用を図る」という視点である ${ }^{13)}$ 。斜面防災 に関して長年にわたって有益な情報を蓄積してきた当学 会には, 山地や丘陵地の安全性に関して, 住民に真に役 立つ有益な情報を積極的に発信していくことが求められ ており，その役割は大きい。

\section{【関連文献】}

1 ）社団法人全国地質調查業協会連合会編（2007）：[小特集］技 術の伝承, 地質と調查, No. 113 , 土木春秋社.

2 ) 張鋒 (2010): 初級講座 技術の伝承一現場の教訓から学ぶー 講座を始めるにあたって, 地盤工学会誌, Vol. 59, No. 10, p. 58. (2007年10月号から 2008 年 3 月号まで 6 回にわたって連 載)

3 ) 鴨井幸彦 (2012)：地すべり調査・対策の現在, 過去, 未来一 新潟県を中心に一, 第40回地すべりシンポジウム 地すべり 研究の現状と展望, pp. 7-10, 地すべり学会新潟支部.

4 ）高野秀夫 (1980)：銀座地すべり, 地すべり, Vol.17, No.1, pp. $45-46$.

5 ) 高野秀夫 (1982)：空論の法則, 地すべり, Vol.19, No.1, pp. $44-45$.

6 ）高野秀夫 (1983) : 斜面と防災, 築地書館, 179p.

7 ) 藤田和夫 (1977)：日本砂山列島, 図書, No. 330, pp. 26-35, 岩波書店.

8 ) 藤田和夫 (1982)：日本列島砂山論, 小学館創造選書49, 136p.

9 ）鴨井幸彦 (2012)：大規模地すべりにどう向き合うか, 斜面防 災技術，Vol. 38，No.3，pp. 52-55.

10）渡正亮（1994）：土工と地すべり（その1）, 地すべり技術, No. 61 , pp. $62-66$.

11）安全率に関する講座委員会（2009）：10. 地すべり分野におけ る安全率に関する座談会. pp. $33-43$, 安全率に関する講座 委員会編, 講座安全率を考える第10回, 日本地すべり学会誌.

12）鴨井幸彦 (2006)：地すべり調査の秘訣 -21 のポイントー, 地 すべり技術, No. 96, pp. 59-64.

13）鴨井幸彦（2013）：防災・減災の決め手は土地（地形・地盤） 条件に合った土地利用にあり, 地盤工学会誌, Vol. 61, No. 3, pp. $22-25$. 